\title{
Value Change and Demographic Behaviour in the Czech Republic ${ }^{*}$
}

\author{
LADISLAV RABUŠIC ** \\ School of Social Studies, Masaryk University, Brno
}

\begin{abstract}
The deep structural changes witnessed in the Czech Republic in the past decade, that is, the establishment of a democratic political regime and market economy, and the transformation of the social security system, could not have steered clear of the everyday life and behavioural patterns of the Czech population. One of the areas that have been profoundly affected is demographic behaviour. Marriage and fertility rates in particular have decreased to an unprecedented level. The main thesis of this paper is that the demographic changes in the Czech Republic result from a condensed progress of the second demographic transition, which was triggered off by a value change in young age cohorts born in the 1970s and early 1980s. The new value orientations of these cohorts, which were latently present even before the political change, manifested themselves fully in the free environment of the new democratic society. The paper will present evidence of the value changes by utilising data from a comparative sociological research titled the European Values Study which was carried out in Europe in 1990/91 and in 1999. It is argued that the coincidence of value and demographic changes can hardly be regarded as accidental.

Czech Sociological Review, 2001, Vol. 9 (No. 1: 99-122)
\end{abstract}

\section{Introduction}

The political, economic and social changes witnessed in the Czech Republic in the past decade are so deep that they could easily be labelled as paradigmatic ones. The establishment of a democratic political regime and market economy, and the transformation of the social security system, could hardly have steered clear of the Czech population's everyday life and behaviour.

One of the spheres of behaviour where the depth of change is easily measured and therefore well documented is demographic behaviour. Czech demographic vital statistics reveal that changes in fertility, marriage and mortality patterns are as profound as those which occurred in the Western countries in the 1970s and 1980s. Thus, the main thesis of this paper is that the demographic phenomenon witnessed in the Czech Republic is in fact a second demographic transition (SDT) started in the mid-1990s. Its causes - as in the West [see e.g. van de Kaa 1987, 1994, 1997; Lesthaeghe 1995] - can be attributed to deep changes in the value preferences of the new age cohorts. While in the Western countries it was the cohorts born in the 1950s and 1960s who were the bearers of the SDT, in the Czech Republic it is the cohorts born in the mid 1970s and early 1980s.

*) Research for this paper was supported financially by the Grant Agency of the Czech Republic (GAČR), research project \# 403/99/0326 European Values Study - The Czech Republic 1999. I acknowledge comments of two anonymous reviewers.

**) Direct all correspondence to Ladislav Rabušic, Department of Sociology, School of Social Studies, Masaryk University, Gorkého 7, 60200 Brno, Czech Republic, e-mail rabu@fss.muni.cz 
Among the main features of the Czech demographic trends, one that has been much discussed in the media, belongs a gradual, year by year decrease in the number of births in 1992. The Czech fertility rate belongs among the lowest ones in the world nowadays. It seems as if kids have been disappearing from the Czech social space. Many Czech politicians and some demographers have already expressed their anxiety about the situation and have even called for action - for the introduction of pro-natal population policy measures.

The causes of the currently low Czech fertility (and low nuptiality as well) have been sought by many Czech analysts, see e.g. Rychtaříková [1996, 1999, 2000], Kuchařová and Tuček [1999], Fialová, Hamplová, Kučera and Vymětalová [2000], Možný and Rabušic [1999] and Rabušic [1996, 1997]. Their views differ, but basically they form an axis, of which one pole is made by explanations based on the hypothesis of the accelerated second demographic transition, and the other pole is made by explanations stressing economic hardships which stem from the transformation of Czech society. Advocates of the first approach, myself included, maintain that the primary cause is the deep value change among the young cohorts. Advocates of the second approach (Rychtaříková) believe that the main cause of changes in marriage and fertility rates are factors of economic crisis: unemployment of the young, the decreased level of social security and the decreased level of the living standard. They regard therefore the behavioural change as a pragmatic reaction to the high costs of transformation.

No camp has managed to bring persuasive evidence so far. However, it is quite clear that the debate follows the interpretative demographic transition scheme established by Jean-Claude Chesnais [1992, quoted by Rychtař́ková 1999]. Chesnais showed that the first demographic transition evolved within the framework of modernisation whose three main components were technological change, structural change (higher living standard, the establishment of social security, increased education) and cultural change (principles of democracy and equality, secularisation, personal freedom). Later on, Van de Kaa [1994] applied this view also to demographic changes recorded during the 1970s and the 1980s, which he labelled as the second demographic transition. According to Van de Kaa [1999], in both demographic transitions cultural changes, i.e. changes of value structures and of people's ideas, played the key role.

From this point of view the Czech debate is carried on in the dimension of structural versus cultural aspects of demographic change. I advocate - without underestimating the importance of structural aspects - factors of culture. Among them I regard especially value change as the primary cause of the current low level of Czech fertility.

I shall argue in this paper that the current Czech demographic transition is a logical, necessary and even unavoidable effect of the Czech 'velvet revolution' and of the subsequent transformation process. It is logical and unavoidable because - as I shall show - its protagonists are the young age groups born in the late 1970s and early 1980s whose value orientations are quite different from those of the older generations. Owing to the conditions of collapsing socialism in the second half of the 1980s and the freedom inherent in the new social order after 1989, these young age groups have gained a totally new experience incomparable to that of previous generations. Their value patterns concerning marriage, the family and children have been changing, and have started to resemble those typical of Western democracies. 
It is thus no coincidence that the 1989 'velvet revolution' was triggered off by the generation born in the late 1960s and socialised during the 1970s. These young people who were brought up in a milieu of relative economic affluence ${ }^{1}$ developed new value structures and value preferences that led them finally to break the communist regime. They paved the way for their followers. While this cohort's values brought about a political revolution, the values of the next cohort, born in the mid-1970s, brought about a demographic one.

My aim is to show the depth of changes which have occurred in the value structures of the Czech population with regard to marriage and family formation and which have had - in my view - a strong impact on recent demographic development. By stressing a value change as the prime cause of a demographic change I am pursuing the line of reasoning advocated for example by Preston [1986], Van de Kaa [1987 and 1998], Kirk [1988] and Lesthaeghe [1995]. The main method I apply is a cohort approach to survey data gathered in the two waves of the European Values Study (1991 and 1999). The presentation of evidence showing value change in the youngest Czech age cohorts will enable me to explain the Czech demographic trends.

\section{Values}

The concept of 'values' belongs among concepts that are used quite often in the social sciences, but as well as many of the other concepts it lacks a universally accepted definition. For the purposes of this paper it is sufficient to use the same simple concept of a value as is proposed by Van Deth [1995]. ${ }^{2}$ I assume here that individual behaviour is determined by motives and intentions which are shaped by values and value orientations. Individuals' values themselves are influenced by the social environment in which they live, especially during their formative years. Values are perceived by Van Deth and Scarbrough [1995: 46] as "conceptions of the desirable which are not directly observable but are evident in moral discourse and relevant to the formulation of attitudes". Among the attitudes, a process of patterning takes place. Meaningful patterns of attitudes are called 'value orientations' by Van Deth and Scarbrough. By means of measuring them we can identify the intentions of human behaviour - and not only that. Hechter, Ranger-Moore, Jasso and Horne [1999: 425] maintain that values do matter, and they even suggest that "values can be incorporated into explanations of macrosocial phenomena".

Values, as experts agree, are relatively stable entities. However, some value clusters can change, and they gradually do - were it not the case, no social change would be possible. In this context, the concept of cohorts is important. Some thirty-five years ago, Ryder [1965] speculated about a cohort, i.e. a group of people who have a certain vital event in common, and social change. He stated that due to the fact that each cohort established new contacts and encountered a specific social heritage, cohort members shared similar behavioural patterns. Thus, in his view, they permit social change. Later on, Riley [1987] expressed the view that cohorts actually contributed to social change on the basis

1) They were often called Husák's children after the communist leader Gustáv Husák, who with his comrades tried to increase the subjective average living standard in the 1970s by 'investing' into consumer durables instead of the Czech infrastructure in a desperate effort to make the Czechs forget the Prague Spring of 1968.

2) Van Deth presents a comprehensive review of the concept in one of the chapters of the quoted book [see Van Deth and Scarbrough 1995]. 
of a "principle of cohort influence on social change" [ibid.: 4]. Since cohorts are socialised under new social conditions they introduce new patterns of behaviour, many of which become new social norms. Van de Kaa [1997] goes even further. Criticising Ryder for a 'dangerously narrow' approach, he claims that "cohorts do not only permit change; they create the options succeeding cohorts have to choose from" [ibid.: 3]. By making choices, people group themselves, according to Van de Kaa, into 'mental cohorts' whose characteristic feature is that "they have acquired a similar approach to life. They share a common outlook and tend to make choices (stereo) typical for that mental cohort" [ibid.: 4]. In my view, the concept of mental cohorts is highly relevant for understanding the abrupt changes in demographic behaviour of the young Czech age cohorts.

Values are constructed and deconstructed, cultures and social groups influence individual behaviour, but at the same time individual value preferences and corresponding behaviour do influence group values. The pace of value change has become faster in contemporary modern societies due to the pervasive influence of mass communication and mass media - the media bring contents of behaviour to large segments of society, thus allowing for greater homogenisation of attitudes and value patterns [Preston 1986] and for a more rapid formation of mental cohorts.

Values are guides of behaviour, including demographic behaviour. Political and economic changes in the Czech Republic have brought about new concepts of the role of individuals in society, of their rights and obligations, and of individual goals and aspirations. Many of them have had a profound impact on demographic behaviour, especially on the establishment of new marriages and on fertility.

\section{The values shift and demographic change}

The Czech Republic, as well as the other countries of the former socialist block, used to be characterised by a unique extensive population regime which differed to a great deal from that established in modern democratic societies. The adjective 'high' was typical for this regime [Vereš 1991]: high marriage rate, high abortion rate, high birth-rate (often realised at the very beginning of one's reproductive period), high divorce rate and high mortality rate. It can be maintained, I believe, that this state had a general and complex cause, and that was the very existence of totalitarian socialism.

The Czech Republic, which from a demographic perspective used to belong to a regime west of the Hajnal's line prior to the totalitarian era, shifted gradually toward the Eastern European regime after February 1948. The mechanism of this shift is apparent. The deeply rooted mechanisms of socialism caused the family to assume a crucial position in the life of an individual, given the social capital (connections) it provided. Socialism, despite being governed by 'the avant-garde force of the working class' and its 'vanguard - the Communist party' who were supposed to guide it to a new modernity, represented in fact a steep regression back to traditional society, where the decisive role pertained less to an individual and an individual's performance than to family networks, clientele and patrons who facilitated the barter trade of services and commodities.

Since every single newly born person used to become the property of the communist state from his/her school-days, there was little leeway for free and independent activ- 
ity. ${ }^{3}$ Boredom was the rule in Czechoslovakia and thus the only authentic act left at the discretion of young people was entering into marriage and giving birth to some two or three children. And so they did. This practice did not change until the outset of the social transformation in the early 1990s when the boredom was (hopefully) over once for all, and the process of establishing a new state and rebuilding capitalism was initiated. It is no coincidence that we have been recording sharp changes in demographic trends since the early 1990s.

\subsection{Changes in the marriage rate}

Childbearing in the Czech Republic usually follows after entering into marriage. Even though there has been a continuous increase in the proportion of children born out of wedlock in the 1990s (from 10\% in 1991 to $21 \%$ in 1999), the majority of Czech children are still born to married spouses. The level of the marriage rate is thus regarded as one of the crucial factors in determining the current fertility rate. Czech demographers even assume that unless it increases the birth rate is not likely to increase either [Kučera 2000]. If this is the case and marriage must still be considered the first step to starting a family, it can be deduced from these data that hesitation about marriage results in fact from low fertility aspirations. ${ }^{4}$

There has really been quite a clear-cut change in the process of marriage formation. The number of marriages has been on a continuous decrease in recent years (see figure 1), the age marriage pattern has been changing (see figure 2) and the average age at first marriage has been increasing. ${ }^{5}$

3) The communist government used to determine young people's life paths, for example, by shamelessly imposing a quota on the number of children who were to attend vocational schools after having completed elementary education. Access to secondary schools was limited, quota on admission to grammar schools were very low. The ratio was strict: $60 \%$ must have attended vocational schools, $40 \%$ other secondary schools.

4) This would mean, as Hans Joachim Hoffmann-Nowotny [1987] interestingly puts it, that the dropping marriage rate is not a cause but a result of the declining willingness to start a family. If this is the case it would mean that the causal relationship between the marriage and fertility rates is converse to what Czech demographers assume: low fertility aspirations lead to a low marriage rate.

${ }^{5}$ ) While in the course of the 1980s the average age of single brides was about 21.7 years according to one-way marriage tables, and the age of grooms was 24.5 years, it increased to 26.2 and 28.5 years, respectively, by 1999. In Western Europe, both figures are still two years higher on average. 
Figure 1. Crude marriage rate in the Czech Republic, 1950-1999

(number of marriages per 1,000 population)

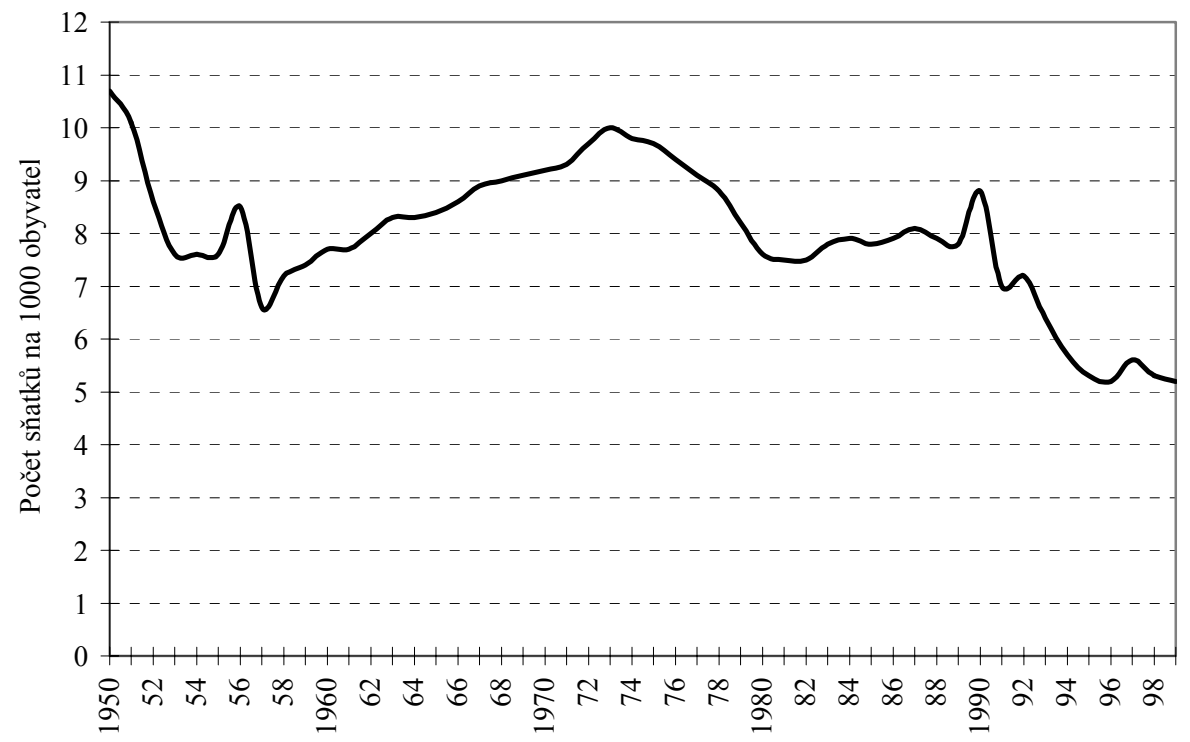

Source: $\quad$ Vital Statistics by the Czech Statistical Office.

Figure 2. Never married women as a share of all women, Czech Republic 1991-1995

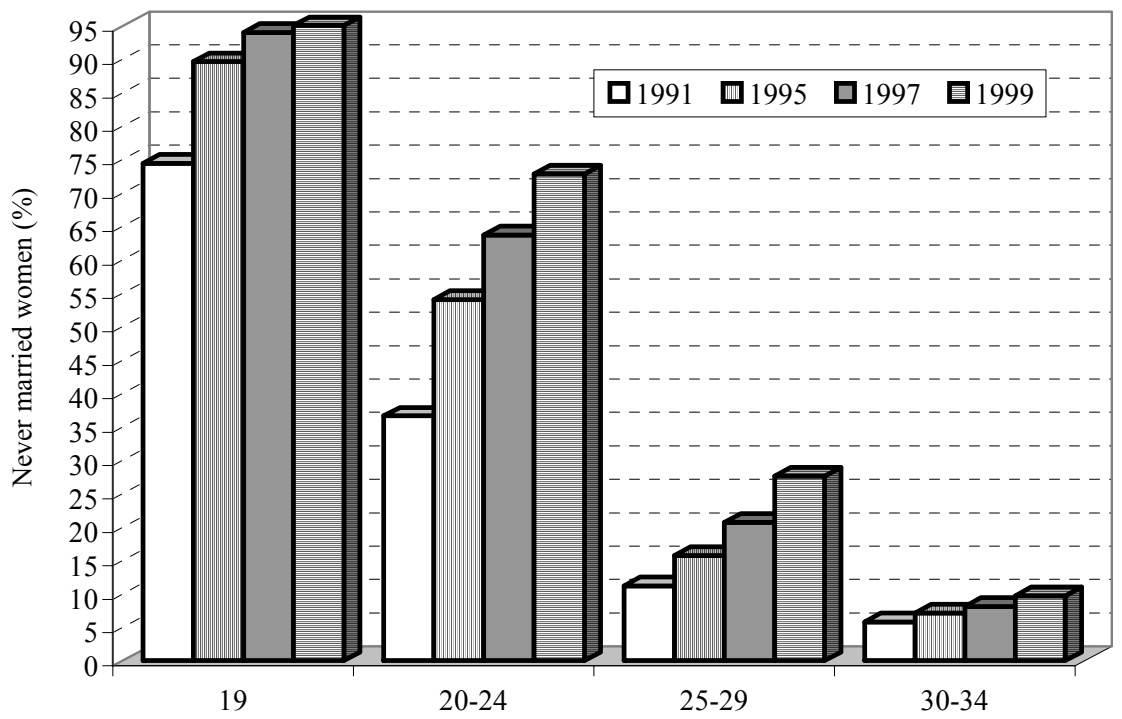

Source: [Kučera and Šimek 2000].

The Czech marriage pattern has shifted from Hajnal's Eastern European marriage regime to the Western one. Why has the marriage rate dropped so suddenly? As expressed in my central thesis, the answer must be sought in a value shift. A very important structural factor appears significant for Czech demographic behaviour: the establishment of a de- 
mocratic, liberal and permissive society has made individualised and free decisionmaking possible. Large segments of the Czech adult population - especially the young ones - have become persuaded that they have a great deal of control over their lives (see table 1). The importance of individual development is stressed by the majority of population (see table 2).

Table 1. Percentage of people who feel that they have a great deal of free choice and control over their lives by age in 1991 and 1999

\begin{tabular}{llcc} 
Age groups & 1991 & 1999 \\
\hline $18-25$ & 47 & 55 \\
$26-33$ & 51 & 60 \\
$34-41$ & 43 & 56 \\
$42-49$ & 37 & 51 \\
\hline Note: & Only age groups within the period of demographic fertility are shown \\
& here. \\
Source: & European Values Study data file, the Czech Republic 1991 and 1999.
\end{tabular}

Table 2. $\quad$ Percentage of people who think that if greater emphasis was placed on the development of the individual, it would be a good thing

\begin{tabular}{llc} 
Age groups & 1991 & 1999 \\
\hline $18-25$ & 87 & 86 \\
$26-33$ & 89 & 90 \\
$34-41$ & 86 & 88 \\
$42-49$ & 88 & 87 \\
\hline Note: & Only age groups within the period of demographic fertility are shown \\
& in the table. \\
Source: & European Values Study data file, the Czech Republic 1991 and 1999.
\end{tabular}

A great many young Czechs thus find themselves with the power to decide their own fate. In addition to the newly opened broad opportunities for exercising one's natural desire for authenticity, this caused the act of entering into marriage and starting a family - formerly the only act of authenticity - to lose its exclusivity. Therefore marriage ceased to be attractive for a significant part of young Czechs. A certain part of society (approximately $20 \%$ in the youngest age groups of the adult population) even considers marriage an obsolete institution (see figure 3). 
Figure 3. Marriage is an outdated institution, Czech Republic 1991 and 1999. Share of respondents who agreed with the statement by age groups

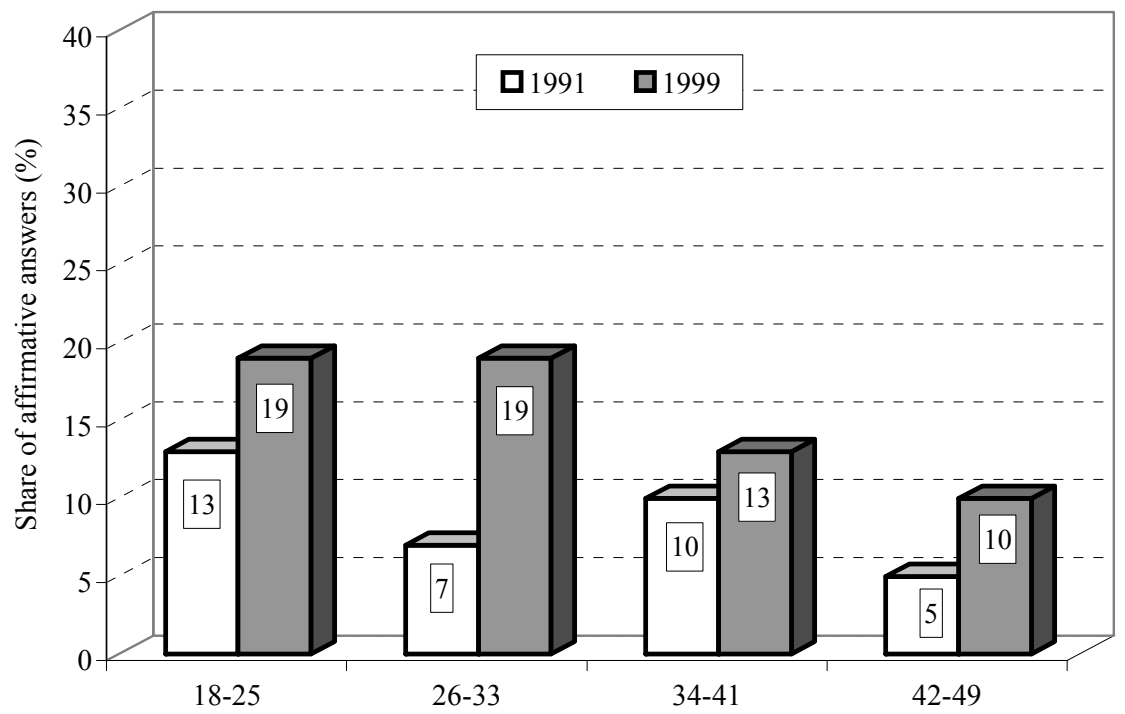

Note: $\quad$ Only fertile age groups are presented, older age groups are omitted.

Source: $\quad$ European Values Study data file, Czech Republic 1991 and 1999.

These value shifts are further reinforced by factors of a structural nature, with which we are familiar owing to international literature which coped with this problem as late as two decades ago. An original explanation scheme of the theory of behaviour in the marriage market and of the rise of unmarried cohabitation - which in many countries accounts for the decrease in the marriage rate - was proposed by Garry Becker [1981]. Let us summarise his main points. Becker grounded his explanation in the economic exchange theory. He started from the assumption that marriage is in fact a business transaction for men and women - they marry because both of them gain more by establishing a marriage (making business) than by remaining single (not trading). In order to maximise profit from marriage, a partner with complementary qualities and skills is usually sought in the marriage market. However, this mechanism changed in the 1970s. Becker suggests that in a situation when women's participation in the labour market is on the increase, and so are their earnings and economic independence, the overall gain associated with marriage decreases. It follows that people have become rather reluctant to seek a match (a business transaction) and it takes them longer to find one. Becker thus believes the growing economic participation and independence of women to be the key factors that lead to postponing marriage (and help to undermine the stability of marriage). According to Westoff [1983], a situation in which it no longer holds that women offer childbearing and household service to a husband in exchange for protection and economic status (derived from the husband's status), marriage loses its rationale.

Also, Oppenheimer [1988] applied the exchange theory to explain new kinds of bonds. She maintains that their rise is related less to the conditions in the labour market than those in the marriage market. Women's higher education, higher employment rate and growing financial independence have pushed up the norm of a match's quality and have altered the image of a minimally acceptable match. From this perspective, it is pos- 
sible, according to Oppenheimer, to perceive the protracted dating period and unmarried cohabitation as an expression of more selective matching.

All these mechanisms obviously could hardly work in the era of egalitarian real socialism. Firstly, there was no real labour market, because getting a job as well as positions within the occupational structure were determined by a number of non-market factors (one of the most important being the loyalty to communist rulers). Secondly, setting up a family relatively early in the course of life - with the least delay possible - was a reasonable coping strategy.

The fact that marriage is no longer a necessary condition for regular sexual activity in contemporary society has also contributed fundamentally to the decreased value of marriage. ${ }^{6}$ At the same time, marriage itself is not a necessary qualification for living together with a partner either since has been replaced - particularly in the period of searching for a stable match - by unmarried cohabitation. Unmarried cohabitation does exist in the Czech Republic. The first Czech data about this phenomenon date back to the mid-1980s owing to research conducted between 1985 and 1986 among engaged couples who were about to marry [see Možný 1987]. The same research was repeated between 1990 and 1991. In 1985-86, the proportion of couples who had cohabited for a certain period of time before getting married was $46 \%$. This proportion even somewhat increased and reached 48\% by 1990-91 [Možný and Rabušic 1992]. ${ }^{7}$ In research from 1997 [Fialová et al. 2000] focusing on attitudes of single people aged 18-29 toward marriage and the family, as much as $67 \%$ of men and $70 \%$ of women stated that they would marry only after having cohabited with the partner. These are cogent indicators of the fact that unmarried cohabitation has become a routine part of intimate life styles in the Czech Republic. And unmarried cohabitation always pushes up the average age at first marriage.

The transformation of attitudes towards marriage and childbearing is certain to reflect what Caldwell calls "westernization" [Caldwell 1976], that is, the fact that owing to global communication, Western ideas and behavioural patterns diffuse internationally. Global communication networks entered the Czech Republic after 1990 and their contents introduced and/or reinforced patterns of late marriages, unmarried cohabitation and outof-wedlock childbearing. In this respect, the Czech Republic has become a "Westernized European" country characterised by corresponding demographic behaviour in the course of the 1990s.

Another macrostructural factor which contributes to postponing marriages and which is, surprisingly enough, highlighted rather rarely in Czech population development analyses $^{8}$ is the increase in the number of persons who have not yet completed their edu-

${ }^{6}$ ) And not just that. It appears that the proportion has decreased of those young Czechs who regard sexual harmony as a very important condition for a successful marriage in the 1990s. As the EVS data from 1991 and 1999 show, while in 1991 as much as 77\% of single respondents in the 18-25 age group considered this aspect important, the proportion dropped to $67 \%$ by 1999 .

7) Interestingly enough, the research falsified the hypothesis that couples who had cohabited before marriage would be more likely to marry because of the bride's pregnancy than those who had not cohabited before marriage. The proportion of pregnant brides among couples who had cohabited was $32 \%$ in 1985-86 and 30\% in 1991-91, while among couples who had not cohabited before marriage the proportion of pregnant brides was higher: $42 \%$ and $38 \%$ in respective years [Možný and Rabušic 1992].

8) With the exception of Kuchařová and Tuček [1999] who pointed to the fact as well. 
cation by the age of twenty - and attend one of the forms of tertiary education. ${ }^{9}$ Such educational opportunities have considerably improved during the 1990s. Absolute numbers of students have increased correspondingly (see table 3) although the figures remain rather low compared with Western European countries. The increase from 89,000 students enrolled in undergraduate and graduate study in 1989, to 188,000 in 1999 is greater than twofold.

Table 3. Numbers of students in tertiary education as a share of the 18-24 population,

$$
\text { CR 1985-1999 }
$$

\begin{tabular}{ccccc}
$\begin{array}{c}\text { Students at three-year } \\
\text { colleges (non-university } \\
\text { education }{ }^{(a)}\end{array}$ & $\begin{array}{c}\text { University } \\
\text { full-time } \\
\text { students (b) }\end{array}$ & $\begin{array}{c}\text { Population } \\
\text { aged 18-24 } \\
\text { (c) }\end{array}$ & $\begin{array}{c}\text { Share of students } \\
\text { per 100 population } \\
\text { aged 18-24(a+b/c) }\end{array}$ \\
\hline $1985 / 1986$ & $\mathrm{x}$ & 87,748 & 963,007 & $9 \%$ \\
$1989 / 1990$ & $\mathrm{x}$ & 88,751 & 980,920 & $9 \%$ \\
$1991 / 1992$ & $\mathrm{x}$ & 94,723 & $1,034,569$ & $9 \%$ \\
$1994 / 1995$ & $\mathrm{x}$ & 115,888 & $1,189,558$ & $10 \%$ \\
$1996 / 1997$ & 13,294 & 136,763 & $1,249,182$ & $12 \%$ \\
$1999 / 2000$ & 27,930 & 159,661 & $1,181,171$ & $16 \%$ \\
\hline
\end{tabular}

+) This type of school was established only in 1995/1996.

*) There are some students, not many, who are older than 24 . This fact though is not a serious distortion of the meaning of such an indicator.

Source: Statistical yearbooks of the Czech Republic.

The fact that 188,000 young people aged $18-24$, that is $16 \%$, are currently enrolled in a tertiary study programme does not leave out the question of marriage behaviour. With respect to marriage and fertility rates, a high level of education constitutes an important determinant, particularly among women. Educated women find themselves in no need of seeking a match in the marriage market who could facilitate their social, economic and status advancement - they find themselves high enough in terms of status even without such a mate. From this perspective, these women do not essentially need marriage at all. Such a shift in women's life orientation is considered by many authors to be one of the most important factors for explaining the overall changes in family structures [see e.g. Westoff 1983, Lesthaeghe 1991-2, Hoffmann-Nowotny 1987, Keyfitz 1987]. The Czech family sociologist Možný [1999] maintains that the value of marriage decreases for a female professional with the level of her professional success, and that the joy of motherhood can be compensated for by her meaningful job. As figure 4 illustrates, the number of women who regard their jobs as an important factor in gaining their independence has been increasing during the 1990s in all age groups. This fact can have an indirect connection with lower levels of marriage and fertility rates.

9) By tertiary education I mean any type of study after the completion of secondary education. 108 
Figure 4. Percentage of respondents who agreed with the statement Having a job is the best way for a woman to be an independent person

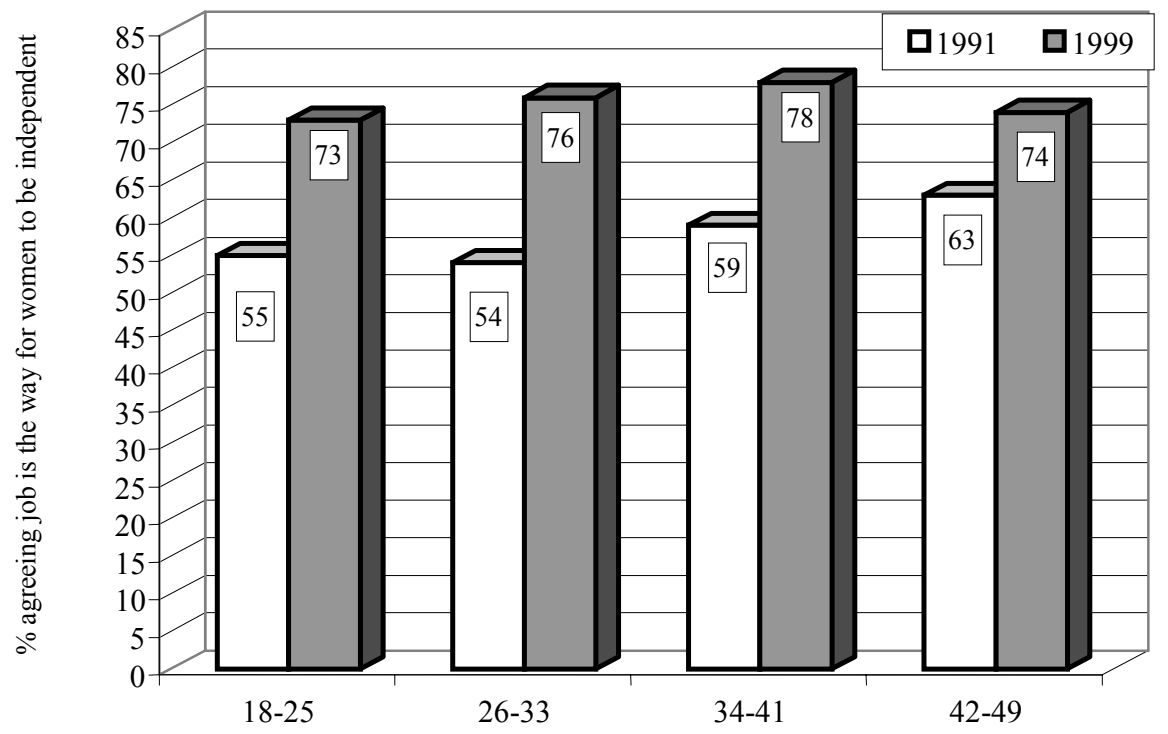

Source: $\quad$ European Values Study data file, Czech Republic 1991 and 1999.

Another structural factor is influential as well, and that is a threat of unemployment among young people. The Czech unemployment rate has been fluctuating around the European average in the recent few years. However, as a phenomenon which is new in the Czech Republic and which impacts the young population in particular ${ }^{10}$ - and let us note that above all young people with low education - it can raise a certain level of anxiety regarding young people's future life plans.

All the above-mentioned arguments clearly demonstrate why we have been witnessing a low marriage rate since the second half of the 1990s. In my view, a low marriage rate appears to reflect a logical and inevitable phase of Czech society's transformation. A low marriage rate is simply an immanent quality of advanced societies since social and economic advancement necessarily brings about a change of demographic behaviour patterns - the second demographic transition.

In the context of the Czech demographic debate, I hold the view that no one and nothing should be blamed for the low marriage rate. It is hardly caused by the current economic and political situation in this country. It would have occurred even had there been an economic paradise here, had politicians born nothing else in mind than public interest, had social security been unswerving and welfare benefits as generous as 'in a fool's paradise'. The transformation of Czech marriage trends has been grounded on a

10) In the late 1999, 120,234 persons in the 20-24 age group out of the total of 889,266 persons of this age were unemployed. In the 25-29 age group it was 63,563 persons out of the total of 825,430 . Of all persons aged 20-24 years $14 \%$ were unemployed and of those aged 25-29 it was $8 \%$. However, these figures cannot be regarded as equal to the unemployment rate since the absolute figures include students and women on maternity leave. If their number was known and was deducted from the total of persons in the given age groups, the proportion of the unemployed would increase. 
new perception of how a young person should handle his/her life - this new social construction of reality, the newly formulated pattern is rather contagious and mental cohorts of this kind are becoming larger and larger. The fact that the contemporary young generation prefers exploring life and providing for oneself over getting married at a low age can be perceived as an expression of their new responsibility regarding their own life and after all - the life of their as yet unborn children.

Obviously, not all young people postpone marriage and not all young people postpone childbearing. Rychtaříková's [1996] finding holds true saying that two models of procreative behaviour continue to mingle in this country: an older one, established in the past and fading away with the generation of 'older' women, and a new one, resembling the Western one, introduced by the strong generation born at the turn of the 1960s and 1970 s and in the first half of the 1970s. Demographic development proves right her proposition that the older model is fading away, and the new one is gaining in its force.

\subsection{Fertility}

Much of what was said about the reasons for the decline in the marriage rate applies naturally to the decline in the fertility rate. Not only that young Czechs postpone marriage, they also postpone childbearing. The result is a steep decline in natality (see figure 5) and fertility (see figure 6). In 1999, the lowest number of children ever recorded in the history of Czech demography was born: $(89,471$ live births), while at the same time it was the forth year in a row with live births fluctuating around 90,000. This is not much compared, for example, with figures from the 1970s or the pre-war years, when there were about 200,000 live births in this country each year.

Figure 5. Live Births in the CR 1920-1999

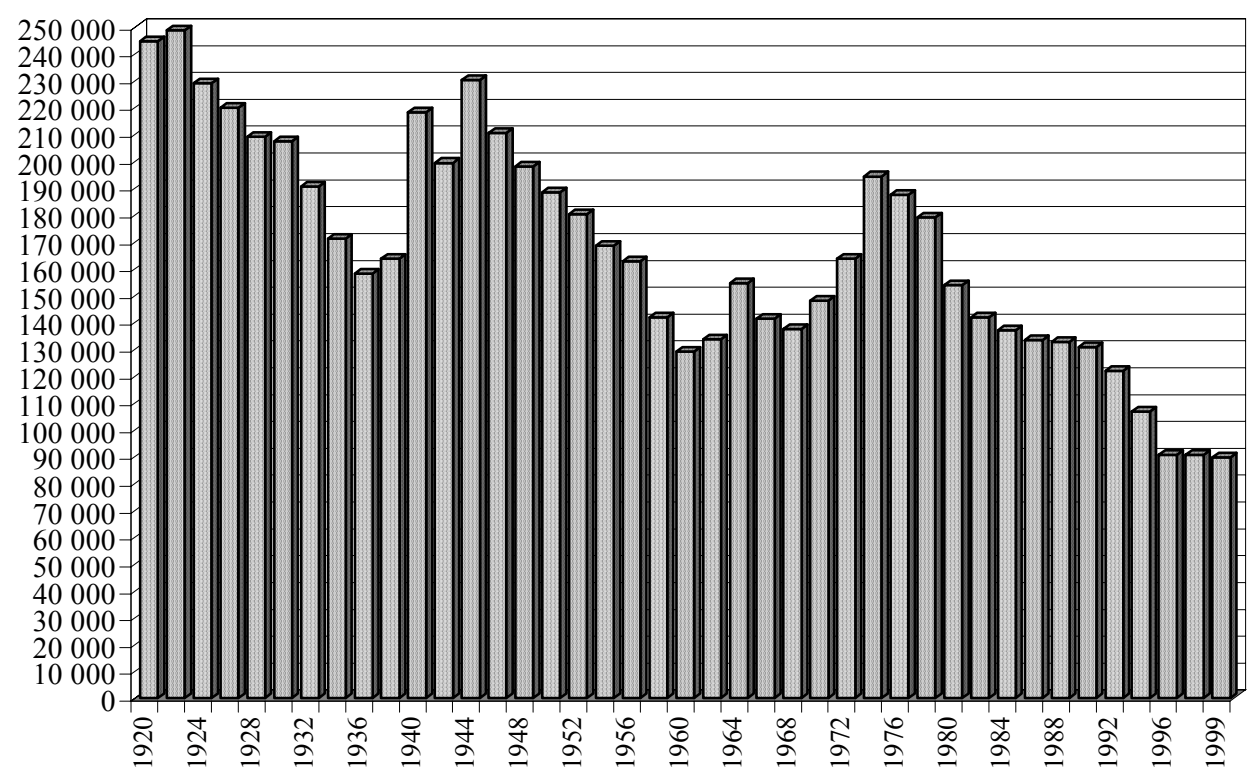

Source: [Kučera 1994: 168-170 for the period of 1920-1992, Populační... 1999], Czech Statistical Office's Internet pages. 
With respect to the total fertility rate, there have been on average 1.2 children born per woman in the recent four years (see figure 6), so that in this respect Czechia presently belongs among the countries with the lowest number of children in the world.

Figure 6. Total fertility rate in the CR 1950-1999 (average number of live births per woman)

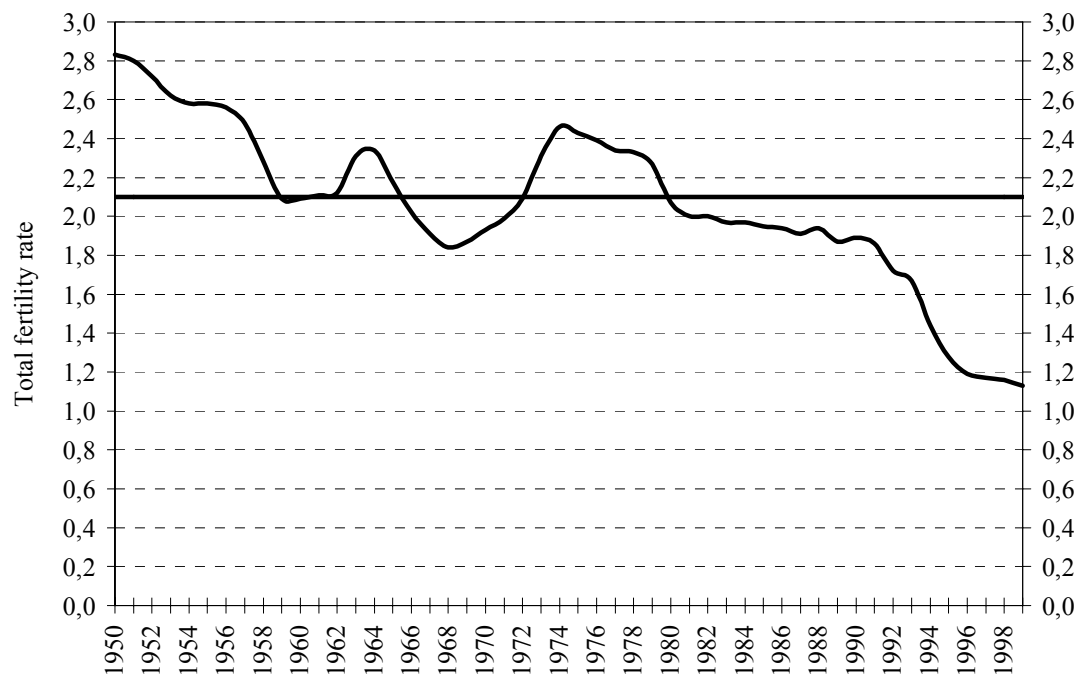

Source: [Kučera 1994, Kučera and Šimek 2000].

This statement, and figure 6 , both require some important commentary. Total fertility rate (TFR) is a great indicator, however, it is not particularly suitable in a period when for whatever reasons sudden changes in the birth-rate occur. This follows from the very definition of this indicator according to which TFR is an estimate of the average number of children born to each woman assuming that the current birth rate remains constant. It is highly likely that the current generation of young women who are to give birth to 1.13 children on average by the end of their reproductive career according to this indicator (since such was the TFR level in 1999) will have more children in the end. Women who postpone childbearing to older age usually tend to squeeze bearing children within a narrow time interval - it is a so-called catching up effect. However, according to Frejka's [2000] cohort fertility analyses, the fertility rate of women born in 1970-71 was, at the age of 26 , lower by $23 \%$ than that of the age group born ten years earlier. The age group born in 1975-76, was, by the age of $21,54 \%$ below the level of the age group born in 1965-66, and there are good reasons to believe that this cohort is likely to wind up with extremely low fertility, he says. What the cohort's completed fertility rate is going to be, will be known in 2020 when the necessary data is available.

A significant feature of Czech reproduction is that fertility shifts from younger to older age groups. ${ }^{11}$ In the 1980 s, children were born to very young spouses so that in many cases in fact it was children who were having children. Figure 7 illustrates this fact. It shows specific fertility in two countries which have already gone through the second transition, Sweden and the Netherlands. While most Dutch women give birth to their

11) This is indicated by the growing average age of mothers at the birth of the first child: 24.8 years in 1989 and 26.6 years in 1998. 
children after reaching the age of 30, the majority of Czech women were still having children between the age of 20 and 25 in 1999. Nonetheless, the shift of fertility to an older age is still clear compared to 1986 . The fertility curve has started to resemble the Swedish one. It will be even more obvious in the next few years, when women who have so far been postponing childbearing and who are currently about 25-26 years old will start having children. They will shift the peak of the specific fertility curve further to the right and closer to the Dutch model.

Figure 7. Age-specific fertility (live births per 1,000 women) in selected countries

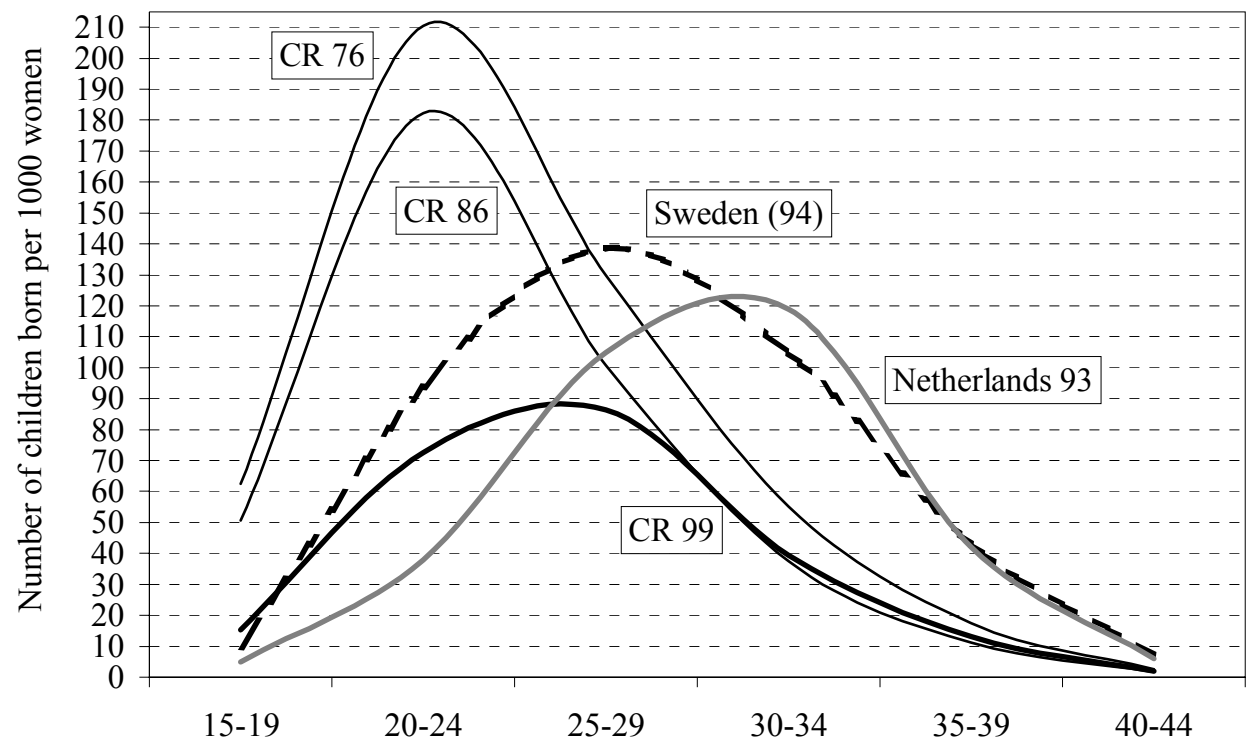

Source: [Populační... 1994, Kučera and Šimek 2000].

The decline in fertility went hand in hand with a decline in the abortion rate in this country during the 1990s (see figure 8). The fact that the lower fertility rate is accompanied by a lower abortion rate indicates that Czech men and women increasingly more often prevent conception by using effective contraceptives. Figure 8 shows that in this respect we are getting nearer to the standards typical of advanced countries where women resort to abortion only in the most inevitable cases and where the abortion index fluctuates between $10-30 \% .{ }^{12}$ This can be perceived as an indicator of the above-mentioned young generation's more responsible attitude to life in general.

12) E.g. $11 \%$ in the Netherlands, $13 \%$ in Spain, 16\% in Finland and Germany, 23\% in France and Norway, 25\% in Great Britain, Italy and Denmark [Populační... 1997: 86]. 
Figure 8. Abortion rate in the Czech Republic, 1958-1999 (number of abortions per 100 live births)

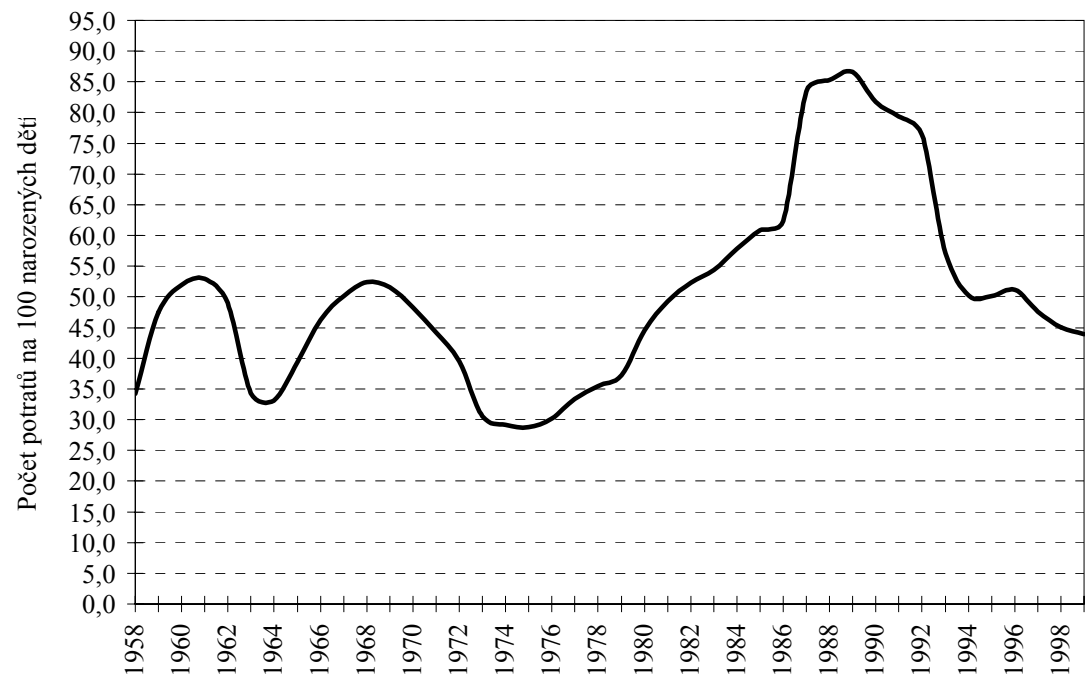

Note: The abortion rate always depends on legislation. Liberal abortion laws, leaving it to women's free discretion whether to have an abortion or not, was enacted in 1986 in the Czech Republic.

Source: [Kučera 1994, Populační... 1999, Kučera and Šimek 2000].

In searching for reasons why there are so few children born in this country, a number of arguments come to mind. For the modernising Czech society, Dumont's (1890) [in Weeks 1999] old propositions about social capillarity are certain to still hold true. $\mathrm{He}$ says that the decrease in the number of births must be attributed to individual social mobility aspirations since these can only be fulfilled with zero or a very low number of children. Also Leroy-Beaulie's (1913) [in Weeks 1999] opinion that low fertility results from individual social aspirations, that is, their pursuit of social advancement (and desire for comfort and luxury), holds equally true.

Desire for success, which naturally includes advancement within the social hierarchy, belongs among the strongest motivations of human activity. As 'to be successful' means 'to be much better than the others' in something, pursuit of success implies competition and triumph. Real socialism blocked natural paths towards success and social mobility based on knowledge, skills, performance and luck. These paths have reopened for the current young generation and it is absolutely understandable that they have been exploring them to the fullest with vehemence peculiar to young age. Postponing conception and lowering the number of children is only a logical consequence of such exploration.

Life of the current young generation is full of opportunities and potentials. Analyses of the value of the child show that emotional gratification represents a key motive for childbearing in modern society [see e.g. Rabušic 2000]. However, as young people's life activities bring about a good deal of satisfaction, the youngest age cohorts no longer derive life fulfilment inevitably and exclusively from having children as is evident from a variety of research data. For instance the EVS data can be the source of such evidence on 
how the context of the value of children and their meaning for individuals has been changing.

In 1999, a total of $60 \%$ of respondents agreed with the statement $A$ man needs to have children in order to be fulfilled. However, figure 9 shows that this attitude differs across age groups. ${ }^{13}$

Figure 9. The share of Czech respondents who agree with the statement that a man needs to have children in order to be fulfilled

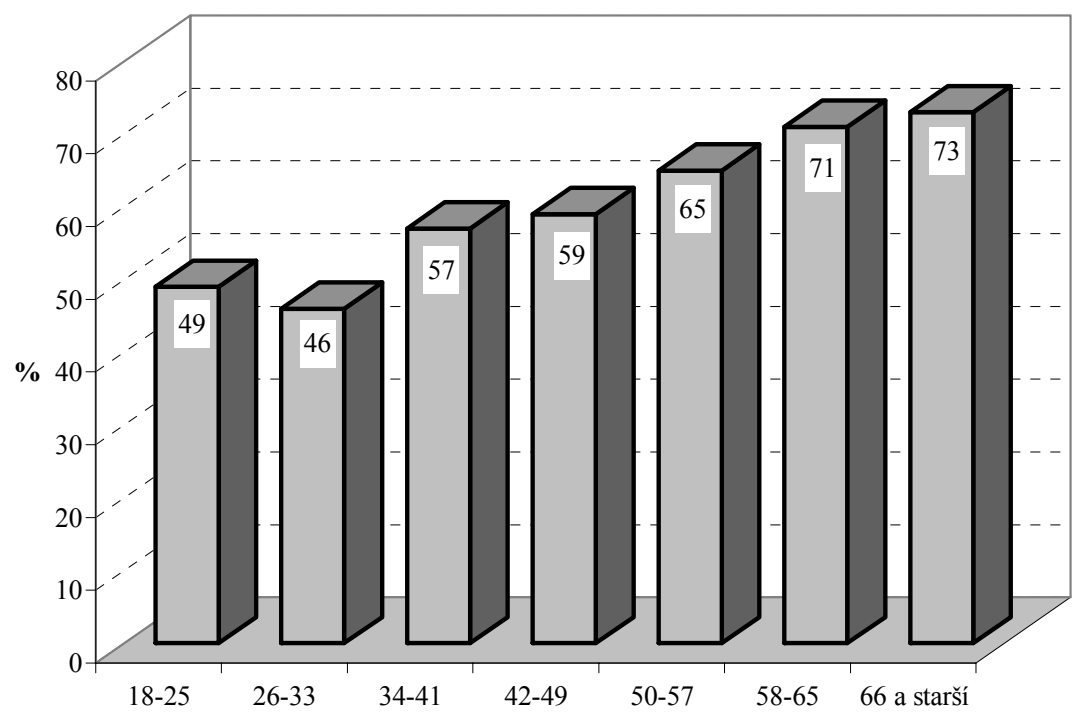

Source: $\quad$ European Values Study data file, Czech Republic 1999.

Yet, a much more significant shift was recorded in the distribution of answers which measured to what extent respondents associate the meaning of female life with children (see figure 10).

13) The young respondents' answers depended on whether they had children at the time of the research or not. While $46 \%$ of childless respondents in the 18-25 age group agreed with the statement, it was only $28 \%$ in the $26-33$ age group and $30 \%$ in the $34-41$ age group. It is highly probable that the rather significant difference is due to the fact that childless respondents aged between 26 and 41 consider children important neither for a person's life in general, nor for their own one. 
Figure 10. The share of Czech respondents who think a women has to have children in order to be fulfilled, by age groups in 1991 and 1999

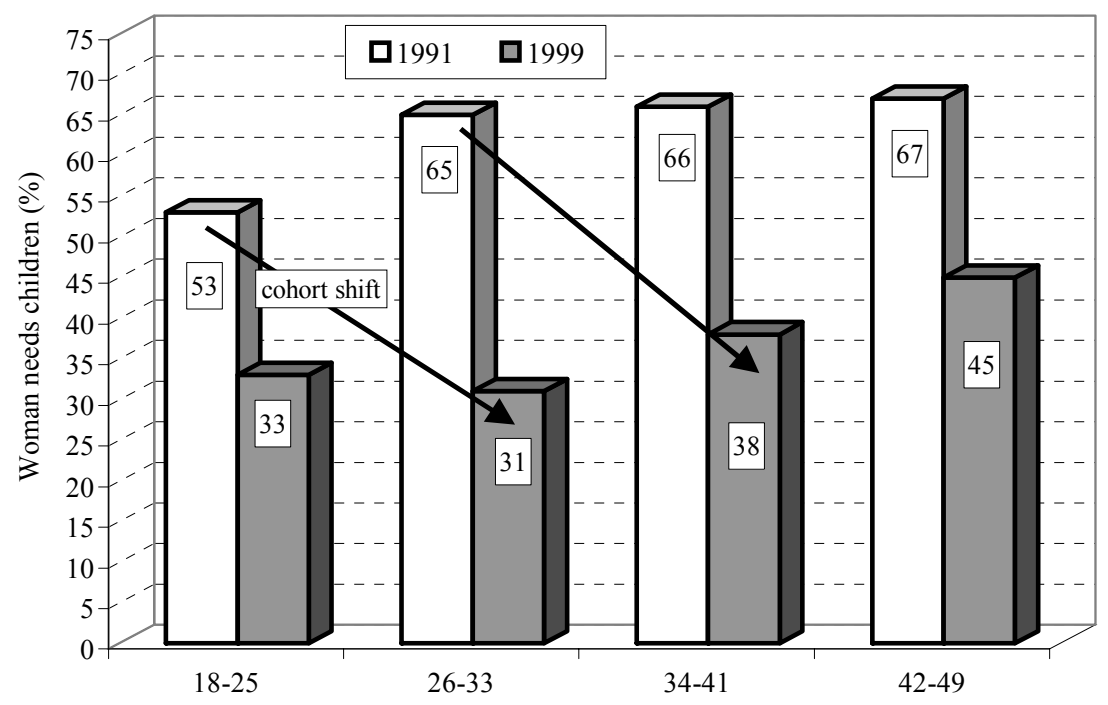

Source: $\quad$ European Values Study data file, Czech republic 1991 and 1999.

The figure shows a deep decline both from the cross-sectional and cohort perspective. Several findings are evident from figure 10. First, from the analytical point of view, attitudes of the 18-25 and 26-33 age groups, that is peak fertility age groups, are important with regards to fertility level and its future development. We can see that a considerable shift has occurred in the course of the 1990s: while in 1991 as much as $53 \%$ of respondents at the age of 18-25 agreed that women need children in order to meet their function, the proportion decreased to $33 \%$ by 1999 . The decrease in agreement was even more apparent in the 26-33 age group: it dropped from $61 \%$ in 1991 to a mere $31 \%$ in 1999 .

A generation attitudinal shift is also apparent. In the environment of a society in transition, the youngest category (18-25 years) have not kept the opinion that they held in 1991 and have changed it. From the original 53\% of those who considered the existence of children significant for women to find meaning in life, only $31 \%$ expressed this attitude eight years later. A similar shift occurred practically in all age groups. ${ }^{14}$

The differences in the young generation's attitudes apparent from figures 9 and 10 are sociologically significant. While only a third of young people aged 18-33 (and only $27 \%$ among childless respondents in the same age group) associates having children with a sense of fulfilment in women's lives, almost a half of the young generation at this age (and $42 \%$ of childless respondents) associates children with a sense of fulfilment in hu-

14) Attitudes of men and women do not significantly differ - the identified four percent difference is negligible in a survey of a representative sample of respondents. However, respondents' opinions differ in dependence on their marriage status: married spouses were more likely to agree (65\% in 1991 and $47 \%$ in 1999) with the statement that a woman needs to have children in order to meet her role than those who were not married ( $45 \%$ and $34 \%$ in the respective years). A certain correlation was identified with regards to whether a respondent had children or was childless. In 1999 a mere $27 \%$ of childless respondents aged $18-33$ agreed with the opinion, while it was $33 \%$ of respondents with children. 
man life in general. This data signals two messages. Firstly, it suggests that significant changes have occurred in the perception of the female role in Czech discourse. The influence of the feminist debate about gender and women's social standing in Czech society is certain to have played a role in this respect. The assumption that children are no longer necessarily associated with female fate, that biology is not a destiny any more, is further reinforced by another finding shown in figure 11. The proportion of respondents who strongly agree with the statement that women do not actually long for work but for children and a home has decreased really sharply in the course of the past eight years. The fall of strong affirmative answers is especially remarkable in the $18-25$ age group. ${ }^{15}$

Figure 11. Percentage of respondents who strongly agree with the statement $A$ job is all right but what most women really want is a home and children, Czech Republic, 1991 and 1999

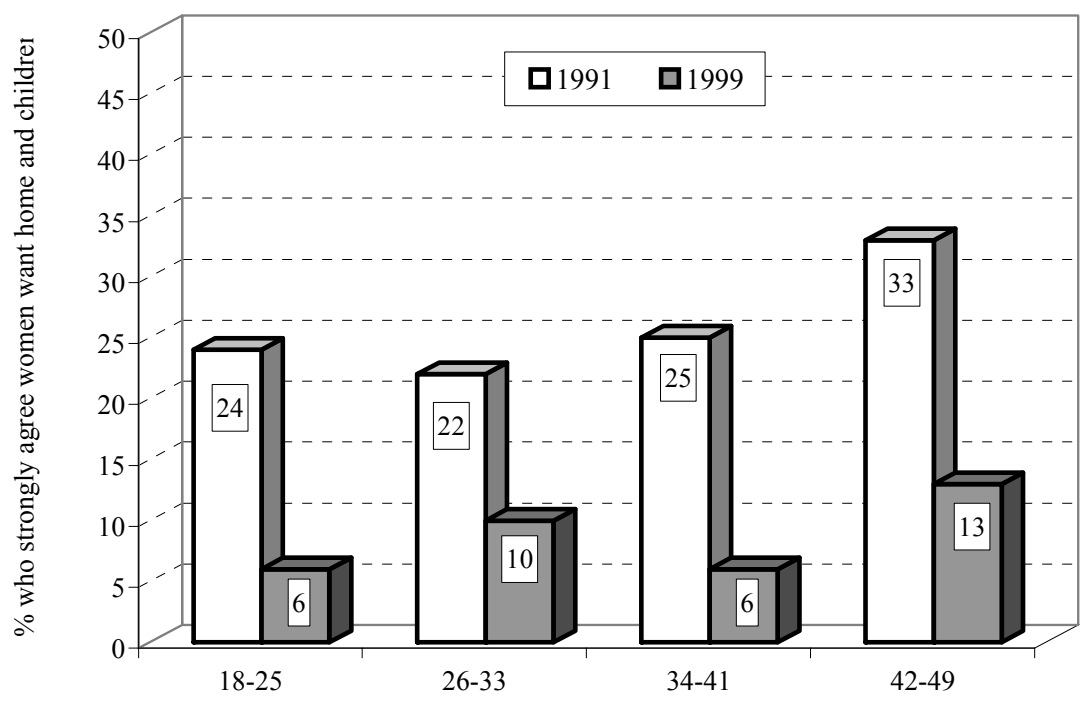

Source: $\quad$ European Values Study data file, Czech Republic 1991 and 1999.

Figures 10 and 11 show quite clearly that the meaning of a woman's life ceased to be perceived by the young Czech population as something which is associated with children and motherhood. This social stereotype has been to a great extent deconstructed and is no longer shared by large segments of the young.

Those who have already started to panic and think that young Czechs have developed anti-natal attitudes could feel alarmed at the second message. Given that $41 \%$ of childless respondents aged 18-33 associate children with one's sense of life, it might seem - on the face of it - that a great proportion of young people are not going to ever have children as they do not consider children necessary for meeting a person's sense of fulfilment. But such causality must not be constructed from the data. Even those who are

${ }^{15}$ ) In the youngest age group, the number of respondents who gave an 'agree' answer has decreased as well (18-25: from 62\% in 1991 to $57 \%$ in 1999). Among respondents aged 26-33, the share remained more or less the same: 57\% in 1991 and 55\% in 1999. 
not quite persuaded as to whether children are inevitable in order for one's life to be meaningful do not necessarily have to remain childless for their lifetime.

The fear of the low level of the future birth rate could even intensify if we consider other data in this context, that is, data from a survey conducted in 1997 on a sample of young people aged 18-30 [Fialová et al. 2000]. When asked about their life plans in the horizon of the following few years with regards to having children, a third of the young said 'rather no' and a fifth said 'definitely no' [Kučera 2000]. Nonetheless, these responses do not unambiguously indicate an anti-natal attitude either. A young person today faces a great many things which they want to experience - Kučera [ibid.] is right in saying that the most fundamental difference in the conditions of demographic behaviour before 1989 and today consists in the opportunity to choose among a variety of activities. This has a crucial impact on the timing of life events. Many of such activities, Kučera says, are so attractive that they are preferred over getting married and having children.

Nevertheless, it is likely that a good many of nearly a half of those young who reported in 1997 not planning to have children in the nearest future will conceive a child in a certain phase of their life cycle. What leads me to this conviction is for example the fact that, according to the 1999 EVS data, 93\% of single respondents believed children to constitute an important prerequisite of a happy marriage. In addition, 95\% of single respondents said that the family was important in their life (EVS 1999). If Foster [2000], who put forth a challenging thesis about the existence of a maternal instinct, is right in proposing that low fertility in advanced countries "is unlikely to fall any lower because women have a biologically based predisposition toward nurturing or maternal behaviour... resulting, in most cases, in a conscious motivation for bearing at least one child" [ibid.: 214] then the gloomy picture of societies full of never married and childless individuals, who react in this way to the demands of modern capitalism and its markets on men's flexibility [Beck 1992], does not necessarily need to materialise. ${ }^{16}$

\section{The meaning of the changes}

What do all these research findings suggest? They suggest that the impact of the transforming social and economic conditions and the political shift from a communist rule towards a democratic one on the population and reproductive attitudes of the young generation is undeniable. Young people started to believe that having a child is not an essential condition for the fulfilment of a woman's role, neither is it necessary for the fulfilment of human life in general. In this context, it is then possible to regard the current low marriage rate as an indicator of low fertility aspirations in the first place, an attitude expressed for example by Hoffmann-Nowotny [1987].

\footnotetext{
16) To state that there is a biological predisposition to certain kinds of human behaviour does not mean that such behaviour cannot vary and that it is necessarily immutable. This is a frequent error made by non-biologists in the understanding of 'predispositions' and 'instincts'. I regard the biosocial approach to fertility as very important, nevertheless many conclusions of evolutionary biologists are not without contradictions. Therefore, we can expect a reaction to Foster's thesis quite soon. A partially opposing thesis already exists. In the same journal, three years earlier, Potts [1997] claimed that unrestrained access to fertility control and abortion which is a characteristic feature of some of the contemporary societies leads on average to very low - i.e. well below replacement level fertility. Voluntary childlessness is one of the causes.
} 
The woman is the carrier of fertility. Thus the changes brought about with modernity and late modernity are important especially for women. Life chances have opened up enormously for them. Besides, the image of a woman socially constructed by feminist ideology makes women turn away from the orientation to early marriage and to early motherhood. I hold the biologists' view that a woman's reproductive strategy differs from that of a man [e.g. Tiger 2000, Ridley 1993]. The female strategy contrary to the male consists in reducing the number of children. Therefore, in such a context, Badinter's [1998] proposition, that once a woman embraces certain social, intellectual and professional ambitions and has resources available to meet these ambitions, she becomes much less attracted by the option of investing time and energy into child care, seems very plausible.

Thus, while the family and motherhood used to be a woman's destiny, they have become a choice nowadays. Women have their fertility perfectly under control owing to modern contraceptive technology ${ }^{17}$ and liberal abortion laws which guarantee that, if a woman does not want to, she will not get pregnant or will not give birth to the child. Emancipated women find marriage to be of little attraction and realise that motherhood and a professional career necessarily rival each other.

Young Czech women used to be acquiesced since the 1950s to the prospect of both being employed and bringing up children at the same time in a certain phase of their life cycle. Socialism with its extensive economic system was in need of great numbers of working people. In the early 1950s, women became a stable component of the work force. The socialist regime did its best to make women not only work but also bear children the future soldiers and work force ready to protect and build up communism. ${ }^{18}$ Indeed, the family and motherhood were rather a destiny than a rational choice under socialism. However, already then there existed a perceived conflict between motherhood, employment and household work which was further reinforced by the fact that there was basically no service sector in Czech society. ${ }^{19}$ Women tried to minimalise the conflict by having children soon after getting married and with short intervals between individual births - according to the strategy 'to do away with childbearing as soon as possible and be done with it once for all'.

In the more or less 'normal' society in which we have found ourselves since the early 1990s, among other things, rationality has been introduced. In line with a rational way of thinking, young men and young women themselves deliberate their future, and it is understandable that they are considerate and cautious in deciding about childbearing.

\footnotetext{
17) Možný [1999] maintains that the importance of this invention for humankind is as epochal as mastering fire or inventing the wheel. He believes this invention has brought about a deep civilisation change the impact of which we are as yet unable to fully reflect and comprehend. I fully agree.

18) There was one more reason why the establishment found it convenient that young people used to hurry with entering into marriage and starting families: Nothing is better for a totalitarian regime than to prevent spontaneous and revolting political activity which is natural for young people by having them be responsible for a partner and children.

19) Možný [1983] presented convincing evidence in the early 1980s. He found that in the case of university educated couples, the woman had often chosen to only have one child, a so-called status child, which had help her gain the status of a mother while sustaining professional performance and aspirations.
} 
Even this can be understood as an expression of the greater responsibility of the current young generation. The effort to secure good conditions for one's prospective children and a good starting position for life is an important moment. ${ }^{20}$ However, this is nothing else than an effort to produce quality children, which according to the microeconomic theory of fertility results in a low number of children. The fact that each generation of Czech women is ever more educated than the previous one increases their opportunity costs which again leads to a reduction in the family size. In line with Ariès's [1980] thesis, in the Czech Republic also, the child has ceased to represent an imperative for sexually active partners and has become one of the possible components of the meaning of human couples' lives.

\section{Conclusion}

In modern societies, life styles and social institutions have changed over the past several decades. Increasingly, cultural factors have become some of the main determinants of change. Ideals of self-betterment, freedom, equality and democratic participation introduced by Western civilisation in the past two or three centuries, have gradually become universal mobilising processes of social change and patterns of human behaviour in most regions of the world [Giddens 1993]. This cultural trait of modern societies has gradually been established so firmly that it is perhaps possible to think of them in terms of a new cultural universal (in Murdoch's sense ${ }^{21}$ ). These cultural factors found their expression in the transformation of marriage and family life patterns and were conceptualised as the second demographic transition.

In this paper, I tried to show that in the Czech Republic, as in other European countries, the second demographic transition has been taking place. As elsewhere, its main cause is a value change in young age cohorts. If we accept Van de Kaa's idea that the second demographic transition is a logical and necessary outcome of modern European development, then the very fact that the Czech Republic has been experiencing this transition as well can be perceived as another indication that Czech society has really been undergoing transformation, and has been entering the family of modern European countries.

Ladislav RaBUŠIC is Associate Professor at the Department of Sociology, School of Social Studies, Masaryk University, Brno. His research is focused on sociological aspects of population trends (e.g. below replacement fertility, ageing), on sociological aspects of social problems (poverty, unemployment) as well as on value change in transforming society. He has been the Czech co-ordinator of the European Values Study project. He published a monograph on ageing Czech society (1995) and edited a book entitled "Czech Society and the Elderly" (1997). Forthcoming is his book "Where Have All the Children Gone - Fertility in Sociological Perspective" (2001).

\footnotetext{
20) Many informal discussions about this issue which I had with young women, both with childless women and mothers, confirm this conclusion.

21) Social anthropologists define cultural universals as such institutions and patterns of behaviour that are found in all known cultures. Anthropologist Peter Murdoch [1945] identified over sixty cultural universals, such as a social status system, marriage, body adornments, dance, myths, incest taboos, puberty customs, inheritance rules, religious rituals.
} 


\section{References}

Ariès, P. 1980. "Two Successive Motivations for the Declining Birth Rate in the West." Pp. 125130 in Determinants of Fertility Trends: Theories Re-Examined, ed. by C. Höhn and R. Mackensen. Liège: IUSSP.

Badinter, E. 1998. Materská láska od 17. storočia po súčasnost' [Maternal Love from the 17th Century to the Present]. Bratislava: Aspekt.

Beck, U. 1992. Risk Society. Towards a New Modernity. Thousand Oaks, London, New Delhi: SAGE Publications. (German original published in 1986).

Becker, G. S. 1981. A Treatise on the Family. Cambridge, MA: Harvard University Press.

Caldwell, J. C. 1976. "Towards a Restatement of Demographic Theory." Population and Development Review 2: 321-366.

Deth, J. W. van 1995. "Introduction. The Impact of Values." Pp. 1-18 in The Impact of Values. Beliefs in Government Volume Four, ed. by J. W. van Deth and E. Scarbrough. Oxford: Oxford University Press.

Deth, J. W van, E. Scarbrough 1995. "The Concept of Values.” Pp. 21-47 in The Impact of Values. Beliefs in Government Volume Four, ed. by J. W. van Deth and E. Scarbrough. Oxford: Oxford University Press.

Dumont, A. 1890. Dépopulation et Civilisation. Étude Démographique. Paris: Lecrosnier et Babé.

Fialová, L., D. Hamplová, M. Kučera, S. Vymětalová 2000. Představy mladých lidí o manželství a rodičovství [Images of Young People about Marriage and Parenthood]. Praha: SLON.

Foster, C. 2000. "The Limits to Low Fertility: A Biosocial Approach." Population and Development Review 26(2): 209-234.

Frejka, T. 2000. “The Czech Republic.” Unpublished manuscript.

Giddens, A. 1993. Sociology. Second Edition. Oxford: Polity Press.

Hechter, M., J. Ranger-Moore, G. Jasso, Ch. Horne 1999. "Do Values Matter? An Analysis of Advance Directives for Medical Treatment." European Sociological Review 15(4): 405-430.

Hoffmann-Nowotny, H.-J. 1987. "The Future of the Family." European Population Conference, Helsinki.

Kaa, D. J. van de 1987. “Europe's Second Demographic Transition.” Population Bulletin 42(1), Washington, DC: Population Reference Bureau.

Kaa, D. J. van de 1994. "The Second Demographic Transition Revisited: Theories and Expectations." Pp. 81-126 in Population and Family in the Low Countries 1993: Late Fertility and Other Current Issues, ed. by G. C. N. Beets, H. van den Brekel, R. Cliquet, G. Dooghe, and J. de Jong Gierveld. Lisse, Berwyn, PA: Swets \& Zeitlinger.

Kaa, D. J. van de 1997. "Options and Sequences: Europe's Demographic Patterns." Journal of the Australian Population Association 14(1): 1-29.

Kaa, D. J. van de 1998. "Postmodern Fertility Preferences: From Changing Value Orientation to New Behaviour." Working Papers in Demography, No. 74, Canberra: The Australian National University.

Kaa, D. J. van de 1999. "Europe and its Population: The Long View.” Pp. 1-49 in European Populations: Unity and Diversity, Vol. 1. Dordrecht/Boston/London: Kluwer Academic Publishers.

Keyfitz, N. 1987. "The Family That Does Not Reproduce Itself." Pp. 139-154 in BellowReplacement Fertility in Industrial Countries: Causes, Consequences, Policies, ed. by K. Davies, M. S. Bernstam, and R. Ricardo-Campbell. Cambridge, UK: Cambridge University Press.

Kirk, M. 1988. Low Fertility, Change in the Family, and Shifting Values. A New European Situation. Wassenaar: NIAS. 
Kučera, M. 1994. "Populace České republiky 1918-1991 [Population of the Czech Republic 19181991]." Acta Demographica XII. Praha: Česká demografická společnost.

Kučera, M. 2000. "Představy o postavení sňatku a narození dětí v životní dráze mladých svobodných lidí [Ideas on the Status of Marriage and Childbearing in the Life Course of Young Singles).” Pp. 45-66 in Představy mladých lidí o manželství a rodičovství, ed. by L. Fialová, D. Hamplová, M. Kučera, and S. Vymětalová. Praha: SLON.

Kučera, M., M. Šimek 2000. "Vývoj obyvatelstva České republiky v roce 1999 [Population Development in the Czech Republic in 1999]." Demografie 42(3): 169-182.

Kuchařová, V., M. Tuček 1999. "Sociálně ekonomické souvislosti změn v demografickém chování mladé generace v České republice [Social and Economic Context of Changes in Demographic Behaviour of the Young Generation in the Czech Republic]." Studie Národohospodářského ústavu Josefa Hlávky, no. 1. Praha: Národohospodářský ústav Josefa Hlávky.

Lesthaeghe, R. 1991-2. "The Second Demographic Transition in Western Countries: An Interpretation." IPD Working Paper. Brussels: Vrije Universitet.

Lesthaeghe, R. 1995. "The Second Demographic Transition in Western Countries: An Interpretation." Pp. 17-62 in Gender and Family Change in Industrialized Countries, ed. by K. Oppenheim-Mason and A. Jensen. IUSSP, Oxford: Clarendon Press.

Možný, I. 1983. Rodina vysokoškolsky vzdělaných manželů [Families of University Graduates]. Brno: FF UJEP.

Možný, I. 1987. "K některým novým jevưm v kulturně legitimních vzorcích rodinných startů [On Some New Phenomena in Culturally Legitimate Patterns of Family Formation]." Demografie 29(2): 114-124.

Možný, I. 1999. Sociologie rodiny [Sociology of the Family]. Praha: SLON.

Možný, I., L. Rabušic 1992. "Unmarried Cohabitation in Czechoslovakia." Czechoslovak Sociological Review, Special issue: 107-117.

Možný, I., L. Rabušic 1999. "The Czech Family, the Marriage Market, and the Reproductive Climate." Pp. 94-112 in Ten Years of Rebuilding Capitalism: Czech Society after 1989, ed. by J. Večerník and P. Matějü. Praha: Academia.

Murdoch, G. P. 1945. "The Common Denominator of Cultures." In The Science of Man in World Crisis, ed. by R. Linton. New York: Columbia University Press.

Oppenheimer, V. K. 1988. “A Theory of Marriage Timing." American Journal of Sociology 94(3): 563-591.

Populačni vývoj České republiky 1994 [Population Development in the Czech Republic 1994]. 1994. Praha: Př́rodovědecká fakulta UK.

Populační vývoj České republiky 1997 [Population Development in the Czech Republic 1997]. 1997. Praha: Př́rodovědecká fakulta UK.

Populačni vývoj České republiky 1999 [Population Development of the Czech Republic in 1999]. 1999. Praha: Př́rodovědecká fakulta UK.

Potts, M. 1997. "Sex and Birth Rate: Human Biology, Demographic Change, and Access to Fertility-Regulation Methods." Population and Development Review 23(1): 1-39.

Preston, S. H. 1986. "Changing Values and Falling Birth Rates." Population and Development Review, Supplement to Vol. 12: 176-195.

Rabušic, L. 1996. “O současném vývoji manželského a rodinného chování v České republice [On Current Development of Marriage and Family Behaviour in the Czech Republic]." Demografie 32(3): 173-180.

Rabušic, L. 1997. "Polemicky k současným změnám charakteru reprodukce v ČR (sociologická perspektiva v demografii) [Polemics on Current Changes of Reproduction in the Czech Republic - sociological perspective]." Demografie 39(2): 114-119. 
Rabušic, L. 2000. "Hodnota dítěte [Value of Children].” Demografie 42(4): 286-290.

Ridley, M. 1993. The Red Queen. Sex and the Evolution of Human Nature. London: Viking.

Riley, M. W. 1987. "On the Significance of Age in Sociology." American Sociological Review 52(1): 1-14.

Rychtaříková, J. 1996. "Současné změny charakteru reprodukce v České republice a mezinárodní situace [Current Changes in the Character of Reproduction in the Czech Republic and the International Situation].” Demografie 38(2): 77-89.

Rychtaříková, J. 1999. "Is Eastern Europe Experiencing a Second Demographic Transition?” Acta Universitatis Carolinae, Geographica 1: 19-44.

Rychtaříková, J. 2000. "Demographic Transition or Demographic Shock in Recent Population Development in the Czech Republic?" Acta Universitatis Carolinae, Geographica 1: 89-102.

Ryder, N. B. 1965. "The Cohort as a Concept in the Study of Social Change." American Sociological Review 30: 843-867.

Tiger, L. 2000. “The Decline of Males.” Society 37(2): 6-9.

Vereš, P. 1991. "Několik úvah o současném a budoucím populačním vývoji [Some Thoughts on Current and Future Population Development]." Demografie 33(2): 97-105.

Weeks, J. R. 1999. Population. An Introduction to Concepts and Issues. Seventh Edition. Belmont, CA: Wadsworth Publishing Company.

Westoff, Ch. F. 1983. "Fertility Decline in the West: Causes and Prospects." Population and Development Review 9(1): 99-104. 